\title{
Aggravated Liver Injury but Attenuated Inflammation in PTPRO-Deficient Mice Following LPS/D-GaIN Induced Fulminant Hepatitis
}

\author{
Xiaochen Wang ${ }^{a}$ Shushan Yana,c Donghua Xu Jun Lia,d Yu Xie ${ }^{a}$ Jiajie Hou \\ Runqiu Jianga Chuanyong Zhanga ${ }^{a}$ Beicheng Sun ${ }^{a}$ \\ aLiver Transplantation Center of the First Affiliated Hospital, Nanjing Medical University, Nanjing, \\ ${ }^{b}$ Department of Rheumatology, the Affiliated Hospital of Weifang Medical University, Weifang, \\ 'Department of Hepatobiliary Surgery, the Traditional Chinese Medicine Hospital of Weifang, Weifang, \\ dDepartment of General Surgery, the Affiliated Jiangning Hospital of Nanjing Medical University, \\ Nanjing, China
}

\section{Key Words}

Fulminant hepatitis - Nuclear factor- $\mathrm{kB}$ - Protein tyrosine phosphatase receptor type $\mathrm{O} \cdot$ Toll-like receptor 4

\begin{abstract}
Background/Aims: Critical roles of PTPRO and TLR4 have been implicated in hepatocellular carcinoma. However, little is known about their modifying effects on inflammation-related diseases in liver, particularly fulminant hepatitis (FH). We aim to investigate the potential role of PTPRO and its interaction with TLR4 in LPS/D-GaIN induced FH. Methods: A LPS/ D-GaIN induced mouse FH model was used. RAW264.7 cells were transfected with PTPRO over-expressed lentiviral plasmids for further investigation. Results: The mortality of PTPRO KO mice is higher than WT mice after LPS/D-GaIN administration. Aggravated liver injury was demonstrated by increased level of serous ALT and AST and numerous hepatic cells death in PTPRO KO mice following LPS/D-GaIN administration. Interestingly, inflammation was attenuated in PTPRO-deficient mice following LPS/D-GaIN administration, which was suggested by decreased inflammatory cytokines (TNF- $\alpha$, IFN- $\gamma$, IL-1 $\beta$, IL-6, IL-17A and IL12 ) and cells infiltrating into spleen (CD3 ${ }^{+} \mathrm{IFN}-\gamma^{+}$cells, $\mathrm{CD} 3^{+} \mathrm{TNF}-\alpha^{+}$cells, $\mathrm{F} 4 / 80^{+} / \mathrm{TLR} 4^{+}$cells). A feedback regulation between PTPRO and TLR4 dependent on NF-KB signaling pathway was demonstrated in vivo and in vitro. Conclusion: PTPRO plays an important role in FH by interacting with TLR4. The crosstalk between PTPRO and TLR4 is a novel bridge linking innate immune and adaptive immune in acute liver injury.
\end{abstract}

X. Wang, S. Yan, D. Xu and J. Li contributed equally to this work.

Beicheng Sun, M.D., Ph.D.

or Chuanyong Zhang, M.D, Ph.D.
Liver Transplantation Center of the First Affiliated Hospital, Nanjing Medical University, 300 Guangzhou Road, 210029 Nanjing, Jiangsu Province, (P.R. China)

E-Mail sunbc@njmu.edu.cn or E-Mail zcy2732@sina.com 


\section{Cellular Physiology Cell Physiol Biochem 2015;37:214-224 \\ \begin{tabular}{ll|l} 
and Biochemistry $10.1159 / 000430346$ & $\begin{array}{l}\text { Dublished online: August 20, } 2015 \\
\text { Po } 2015 \text { S. Karger AG, Basel } \\
\text { www.karger.com/cpb }\end{array}$ \\
\cline { 2 - 3 }
\end{tabular}}

\section{Introduction}

Fulminant hepatitis (FH) is a fatal clinical syndrome with multiple causes, which is most commonly caused by hepatitis B or C viruses and autoimmune factors. Its incidence is fewer than 10 cases per million persons per year in the developed world [1]; nonetheless, nearly $90 \%$ patients with FH die prior to the availability of liver transplantation [2]. Hepatic dysfunction, abnormal liver biochemical values, and coagulopathy are common clinical presentations of FH. Encephalopathy may develop with multi-organ failure and death occurring in up to half of the cases [3]. Excessive activation and dysfunction of lymphocytes and generation of various inflammatory mediators are main immune disorders implicated in FH, contributing to massive necrosis and apoptosis of hepatocytes, systemic inflammation and fulminant hepatic failure. In addition, activation of toll-like receptors (TLRs) and its downstream signaling molecules are also involved in FH [4, 5]. Macrophages are considered to play a critical role in the initiation, progression of acute liver injury as well as the resolution of liver damage in viral hepatitis [6]. Lipopolysaccharide (LPS) in combination with D-galactosamine (D-GaIN) induced FH is a well-established model of macrophagemediated acute liver injury [7].

Toll-like receptor 4 (TLR4) is one of the most intensively studied TLRs family members, which is primarily expressed on macrophages. It detects LPS from Gram-negative bacteria and thus plays a fundamental role in pathogen recognition and activation of the innate immune system. TLR4 signaling pathway plays a pivotal role in LPS/TLR4-induced acute liver injury [8], virus induced acute liver injury [9], and inflammation-related hepatic malignancies [10, 11]. We have previously found that the interaction of TLR4 and protein tyrosine phosphatase receptor type O (PTPRO) in hepatocellular carcinogenesis and progression [12]. PTPRO is one of the receptor types of phosphor tyrosine phosphatases (PTPs), recognized as a tumor suppressor in several kinds of cancer, such as hepatocellular carcinoma (HCC), lung cancer, and breast cancer [13-15]. Besides, PTPRO confers multiple effects on inflammatory diseases in liver $[16,17]$. However, little is known about the interaction between PTPRO and TLR4 and their specific molecular mechanisms involved in FH. Thus, we aim to investigate the crosstalk of PTPRO and TLR4 signaling in LPS/D-GaIN induced FH. Given that intrahepatic macrophages are the main activated immune cells involved in LPS/D-GaIN induced FH and play a principle role in acute liver cells injury, we also use murine cell lines RAW264.7 and PTPRO-overexpressed RAW264.7 in vitro to elucidate their roles in acute inflammatory response.

\section{Material and Methods}

LPS/D-GaIN induced acute liver injury model

Eight- to ten-week-old male C57BL/6 wide type (WT) mice were purchased from the Laboratory Animal Center of Nanjing Medical University. The PTPRO-knockout (KO) C57BL/6 mice were generously gifted by Dr. John L. Bixby (University of Miami, Miami, FL) and were bred and maintained in the Laboratory Animal Center of Nanjing Medical University. All mice were maintained under specific pathogen-free facilities. All experiments were carried out in accordance with the guidelines outlined in the Guide for the Care and Use of Laboratory Animals. FH mice model were constructed by intra-peritoneal (IP) injection with $10 \mathrm{mg} / \mathrm{kg}$ LPS (Sigma Chemical San Diego, CA, USA) in combination with 300mg/kg D-GaIN (Sigma Chemical San Diego, CA, USA) as described in a previous study [8]. Mice in control group were injected with phosphate buffered saline (PBS). Long-term survival condition was observed at time points $4 \mathrm{~h}, 24 \mathrm{~h}, 36 \mathrm{~h}$ and $48 \mathrm{~h}$ after injection of LPS and D-GaIN.

Cell lines culture and transfection

RAW264.7 cell-line were maintained in Dulbecco's modified Eagle's medium (DMEM) medium (Invitrogen Corp., Grand Island, NY, USA) added with 10\% heat-inactivated fetal bovine serum (FBS) (Gibco, Carlsbad, CA, USA), $2 \mathrm{mML}$-glutamine, $100 \mathrm{U} / \mathrm{ml}$ penicillin, and $100 \mathrm{mg} / \mathrm{ml}$ streptomycin with $5 \% \mathrm{CO}_{2}$ at 


\section{Cellular Physiology Cell Physiol Biochem 2015;37:214-224 \begin{tabular}{ll|l} 
and Biochemistry & $\begin{array}{l}\text { DOI: 10.1159/000430346 } \\
\text { Published online: August 20, 2015 }\end{array}$ & $\begin{array}{l}\text { O 2015 S. Karger AG, Basel } \\
\text { www.karger.com/cpb }\end{array}$ \\
\cline { 2 - 3 }
\end{tabular} \\ Wang et al.: PTPRO and TLR4 in Fulminant Hepatitis}

$37{ }^{\circ} \mathrm{C}$. RAW264.7 cells were transfected as previously described [18]. Briefly, Clone ExpressTM II One Step Cloning Kit (Vazyme biotech co.,Itd.) was used to construct the PLV-PTPRO-GFP plasmid according to the manufacturer's recommendations. $293 \mathrm{~T}$ cell supernatant was collected at $72 \mathrm{~h}$ and applied as source of the pressed protein (PLV-PTPRO-GFP). PLV-PTPRO-GFP plasmid was transfected to $0.5-1.0 \times 10^{6}$ RAW264.7 cells accompanied with polybrene reagent.

Spleen lymphocytes preparation

Spleen lymphocytes were isolated as previously described [19]. Briefly, mouse spleen were removed and then pressed through a 70um cell strainer (BD), suspended in Roswell Park Memorial Institute (RPMI) 1640 medium (Life Technologies, BRL), subsequently centrifuged at $500 \mathrm{~g}$ for $5 \mathrm{~min}$. Supernatants containing spleen lymphocytes were collected and then washed with PBS. Cells were resuspended with 40\% Percoll (Sigma-Aldrich, St. Louis, MO) in RPMI 1640 medium. The cell suspension was added onto 70\% Percoll gently and centrifuged for $20 \mathrm{~min}$ at $750 \mathrm{~g}$. Cells from the interphase were collected and washed twice with PBS. Then cells were treated with RBC Lysis Solution (BD) according to the protocol.

Assay for serum transaminase activity

Mice were sacrificed at $4 \mathrm{~h}$ after IP injection of LPS and D-GaIN. Serum samples were collected for analysis. Serum alanine aminotransferase (ALT) and aspartate aminotransferase (AST) activities were detected with the serum transaminase test kit (Rong Sheng, Shanghai, China) based on the protocol.

Cytokine analysis

Samples from cell culture supernatant or serum were collected for cytokines assay. Mouse enzymelinked immunosorbent assay (ELISA) kits were used to detect TNF- $\alpha$, IFN- $\gamma$, IL-1 $\beta$, IL-6 (Dakewe Biotech, China), IL-17A (eBioscience Inc. San Diego, CA) and IL-12 (R and D Systems, USA) in accordance with the manufacturer's recommendations.

Flow cytometry analysis (FCA)

Spleen lymphocytes were centrifugated at $450 \mathrm{~g}$ for $10 \mathrm{~min}$ and then fixed and permeabilized by using a cell fixation/permeabilization kit (BD Pharmingen). Briefly, the resuspended cells were incubated in $100 \mu \mathrm{l}$ of BD Cytofix/Cytoperm solution for $20 \mathrm{~min}$ at $4^{\circ} \mathrm{C}$. After that, cells were incubated with FITC-conjugated anti-mouse TNF- $\alpha$ (eBioscience Inc. San Diego, CA), APC-conjugated anti-mouse IFN- $\gamma$ (eBioscience Inc. San Diego, CA) and PE-conjugated anti-mouse IL-4 (eBioscience Inc. San Diego, CA) monoclonal antibodies or corresponding isotype control (eBioscience Inc. San Diego, CA) at $37^{\circ} \mathrm{C}$ for $1 \mathrm{~h}$. Cells were finally resuspended in PBS and analyzed on a FACS Calibur flow cytometer equipped with CellQuest software (BD Biosciences).

Real-time polymerase chain reaction (PCR)

Total RNAs of cells and fresh mice liver samples were extracted with TRIzol reagent (Invitrogen) and quantized. Real-time PCR was performed to evaluate the level of TNF- $\alpha$, IFN- $\gamma$, IL-1 $\beta$, IL-6, IL-17A and IL-12 with SYBR Green Mastermix kit (Takara) on the Step one plus machine (Applied Biosystems, Darmstadt, Germany) and analyzed in triplicate assays. Primers used were presented in Table 1.

Table 1. Primers used

\begin{tabular}{lll}
\hline Genes & Forward $\left(5^{\prime} \sim 3^{\prime}\right)$ & Reverse $\left(5^{\prime} \sim 3^{\prime}\right)$ \\
\hline TNF- $\alpha$ & TCTTGAGGCCACTTTCTGCT & ACTCATCCTCCACGTCCTTG \\
IFN- $\gamma$ & TGATTTCCTGGCCTTCATTC & ACAGAGGGCCAAAAAGGTCT \\
IL-1 $\beta$ & TGCAGAGTTCCCCAACTGGTACATC & GTGCTGCCTAATGTCCCCTTGAATC \\
IL-6 & AGGAAGCGGTCCAGGTAGTT & CTCCCAAGTCCTCCATAGCAG \\
PTPR0 & GAGGTGAACCCTAACGTGGTG & TCATGGAGACTAGCCTCACCC \\
GAPDH & GCCTCGTCCCGTAGACAAAA & GATGGGCTTCCCGTTGATGA \\
TLR4 & TCAGAACTTCAGTGGCTGGAT & GTCTCCACAGCCACCAGATTC \\
IL-17A & TCAGCGTGTCCAAACACTGAG & CGCCAAGGGAGTTAAAGACTT \\
IL-12 & TACTAGAGAGACTTCTTCCACAACAAGAG & TCTGGTACATCTTCAAGTCCTCATAGA \\
\hline
\end{tabular}




\section{Cellular Physiology Cell Physiol Biochem 2015;37:214-224 \begin{tabular}{c|c|c|c|}
\hline DOI: 10.1159/000430346 & (c) 2015 S. Karger AG, Basel
\end{tabular} \begin{tabular}{l|l} 
and Biochemistry Published online: August 20, 2015 & www.karger.com/cpb
\end{tabular}}

Wang et al.: PTPRO and TLR4 in Fulminant Hepatitis

Western blot analysis

Proteins extracted from cultured cells and fresh liver tissues were quantified with the Bradford assay (Bio-Rad Laboratories, Hercules, CA). Samples were lysed with RIPA buffer plus fresh protease and phosphatase inhibitors. Protein samples $(30 \mu \mathrm{g})$ were separated by SDS-PAGE, transferred to a PVDF membrane, and then incubated with specific antibodies of PTPRO (Proteintech Group), TLR4 (Santa Cruz),

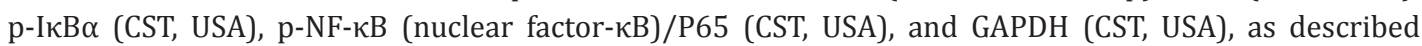
previously [18].

TUNEL assay, H\&E staining, and immunohistochemistry

The TUNEL apoptosis test was performed with a TUNEL Apoptosis Detection Kit (Vazyme biotech, China) as described in the manufacturer's instructions. H\&E staining was performed to estimate liver injury according to a standard protocol. Immunohistochemistry against $\mathrm{p}-\mathrm{NF}-\mathrm{\kappa B}$ was performed on paraffinembedded sections.

\section{Immunofluorescence}

RAW264.7 cells were incubated with or without LPS $(0.5 \mathrm{ug} / \mathrm{ml})$ and D-GaIN $(2.5 \mathrm{mM})$ for $2 \mathrm{~h}$; the phosphorylation level of NF- $\mathrm{\kappa B}$ was detected by immunofluorescence. Cells were visualized using Confocal Laser Scanning Microscope after nuclear staining with the UltraCruzTM Mounting Medium (Santa Cruz).

\section{Statistical analysis}

Results are expressed as mean \pm SEM. Unpaired Student $t$ test was used to compare two groups. Pearson correlation and linear regression analysis were used to determine the correlations between parameters as appropriate. Software of SPSS and GraphPad were used when performing all statistical analyses, and twotailed tests were applied to all data if not specified. Statistically significant p value of 0.05 ( $95 \%$ confidence interval) was considered.

\section{Results}

Low survival rate due to PTPRO depletion in LPS/D-GaIN induced FH mice

Figure 1 showed the survival status of PTPRO-WT and -KO mice following IP injection of LPS and D-GaIN. After the administration of LPS/D-GaIN for 4 hours, PTPRO-KO mice appeared reduced activity and shivering with hair stand in end, while WT mice were in good survival conditions with normal activity and spirit. After 24 hours, death occurred in PTPROKO mice with a mortality of $2 / 10$. No death was observed in WT mice although they were in poor state. At 36h, 8 in 10 of PTPRO-KO mice died; however, only 6 in 10 of WT mice died after LPS/D-GaIN administration. At 48h, all rest PTPRO-WT and -KO mice died. In addition, mice with PBS injection were all in good conditions throughout the experiment.

Fig. 1. Cumulative survival of PTPRO KO and WT mice after administration of LPS/D-GaIN ( $n=10$ ) The living condition of mice was evaluated at $4 \mathrm{~h}, 24 \mathrm{~h}$, $36 \mathrm{~h}$ and $48 \mathrm{~h}$ after LPS/DGaIN injection.

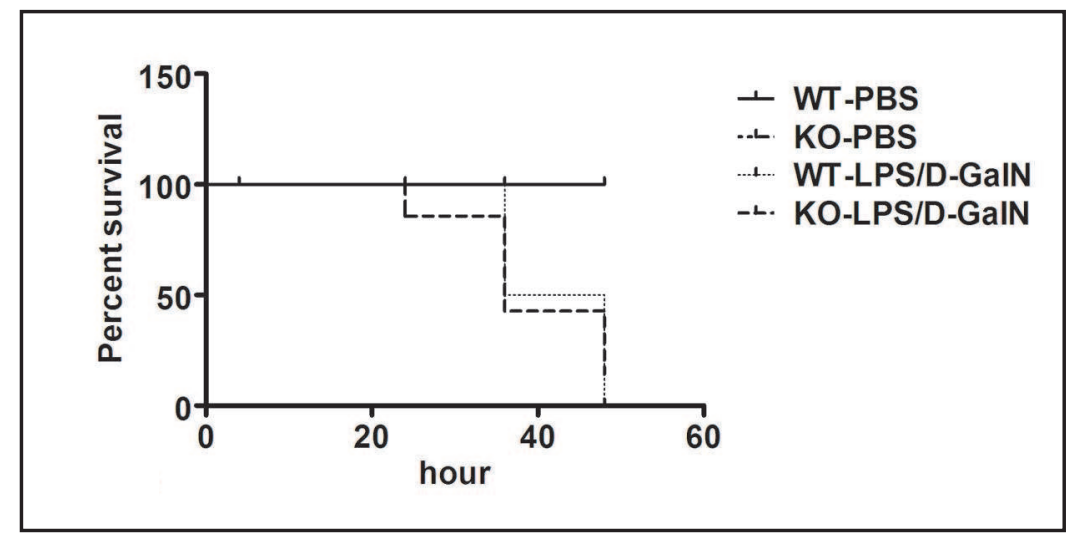




\section{Cellular Physiology Cell Physiol Biochem 2015;37:214-224 \begin{tabular}{ll|l} 
and Biochemistry & $\begin{array}{l}\text { DOI: 10.1159/000430346 } \\
\text { Published online: August 20, } 2015\end{array}$ & $\begin{array}{l}\text { C 2015 S. Karger AG, Basel } \\
\text { www.karger.com/cpb }\end{array}$ \\
\hline
\end{tabular}}

A

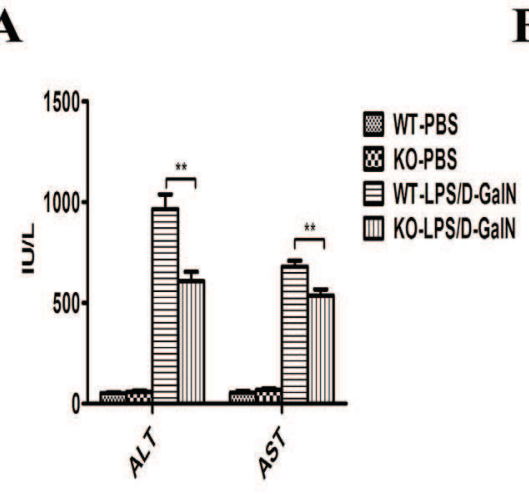

B

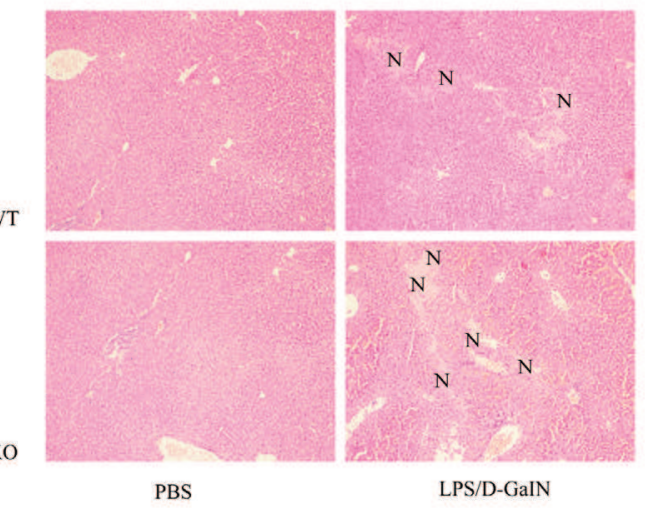

C

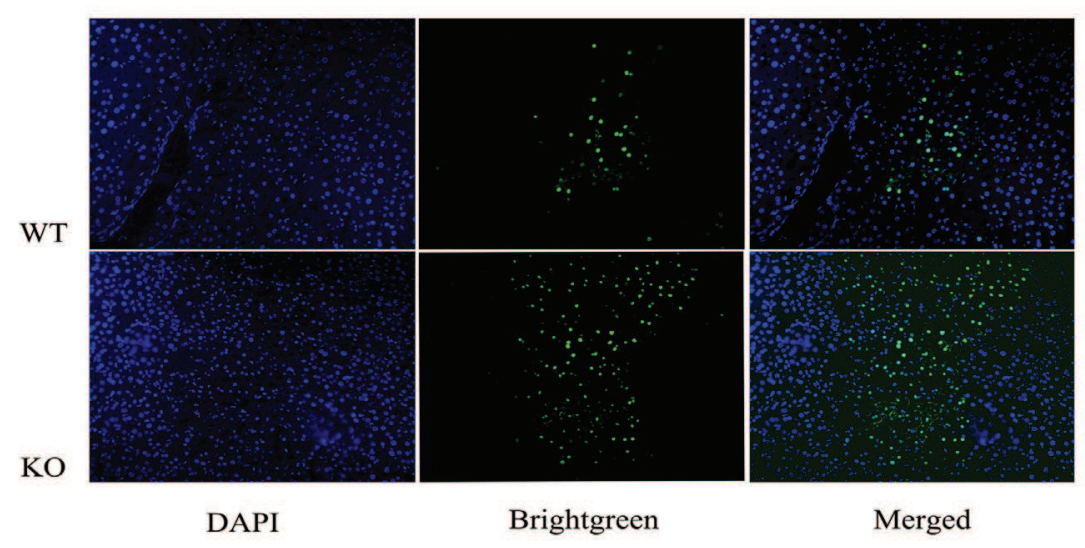

Fig. 2. Elevated liver injury due to PTPRO depletion in a LPS/D-GaIN induced mouse fulminant hepatitis model. (A) Level of ALT and AST in LPS/D-GaIN induced mouse fulminant hepatitis model (n=6). (B) $\mathrm{H} \& \mathrm{E}$ staining for mouse livers after LPS/D-GaIN administration for $24 \mathrm{~h}(\mathrm{X} 100, \mathrm{n}=6$; " $N$ " is representative of necrotic tissue in livers). (C) TUNEL assay for mouse livers after LPS/D-GaIN administration (X100, n=6) (** $\left.P<0.01,{ }^{* * *} P<0.001\right)$.

\section{Aggravated liver injury in PTPRO-deficient mice following LPS/D-GaIN administration}

After LPS/D-GaIN injection for 4 hours, significantly elevated level of ALT and AST was found in the serum of PTPRO-KO and -WT mice (Fig. 2A). H\&E staining showed more necrosis and fewer integrated liver lobules in PTPRO-KO mice compared with PTPRO-WT mice (Fig. 2B). Besides, more hepatocytes apoptosis occurred as a result of PTPRO depletion by TUNEL assay (Fig. 2C). Taken together, sever liver damage occurred in FH due to PTPRO depletion.

Attenuated inflammation due to PTPRO depletion through inhibiting TLR4

In contrast to PTPRO-WT mice, decreased mRNA level of inflammatory cytokines including TNF- $\alpha$, IFN- $\gamma$, IL-1 $\beta$, IL-6, IL-17A and IL-12 was observed in PTPRO-KO liver tissues (Fig. 3A and Fig. 5A). Besides, lower level of IFN- $\gamma$, IL-1 $\beta$, IL-17A and IL-12 was found in the serum of PTPRO-KO mice when comparing with that of PTPRO-WT mice (Fig. 3B and Fig. 5B). No statistically significant difference for serous TNF- $\alpha$ and IL- 6 was demonstrated between PTPRO-WT and -KO mice (Fig. 3B). All those findings implicated attenuated inflammation in LPS/D-GaIN induced FH mice because of PTPRO depletion. Moreover, as detected by flow cytometry, significantly decreased CD3 ${ }^{+} \mathrm{IFN}-\mathrm{r}^{+}$cells and $\mathrm{CD} 3^{+} \mathrm{TNF}-\alpha^{+}$cells infiltrated into the spleen of PTPRO-KO mice in comparison with PTPRO-WT mice, while no significant variation was detected for $\mathrm{CD}^{+} \mathrm{IL}^{-} 4^{+}$cells in mice spleens (Fig. 3C). We further determined the level of $\mathrm{F} 4 / 80^{+} / \mathrm{TLR} 4^{+}$macrophages in mice spleens, because they are the 


\section{Cellular Physiology Cell Physiol Biochem 2015;37:214-224 \begin{tabular}{l|l}
${ } }$ & \\
and Biochemistry Published online: August 20, 2015 & $\begin{array}{l}\text { O 2015 S. Karger AG, Basel } \\
\text { www.karger.com/cpb }\end{array}$ \\
\cline { 2 - 3 }
\end{tabular}

Fig. 3. Attenuated inflammation in LPS/DGaIN induced fulminant hepatitis of PTPRO knockout mice. (A) Level of TNF- $\alpha$, IFN- $\gamma$, IL- $1 \beta$ and IL-6 mRNA in mice liver $(n=6)$. (B) Level of TNF- $\alpha$, IFN- $\gamma$, IL-1 $\beta$ and IL- 6 protein in mice serum $(n=6) .(C)$ Level of $\mathrm{CD}^{+}{ }^{+} \mathrm{FN}-\mathrm{r}^{+}, \mathrm{CD}^{+} \mathrm{T}-$ $\mathrm{NF}-\alpha^{+}$and $\quad \mathrm{CD}^{+} \mathrm{IL}^{-} 4^{+}$ cells in mice spleen $(\mathrm{n}=6)$.(D) Level of F4/80+TLR4 ${ }^{+}$cells in mice spleen $(n=6)$. (E) Level of TLR4 and PTPRO mRNA in mice liver $(n=6)$. (F) Level of TLR4 and PTPRO protein in mice liver $(\mathrm{n}=6)\left({ }^{* *} P<\right.$ $0.01,{ }^{* * *} P<0.001$ ).

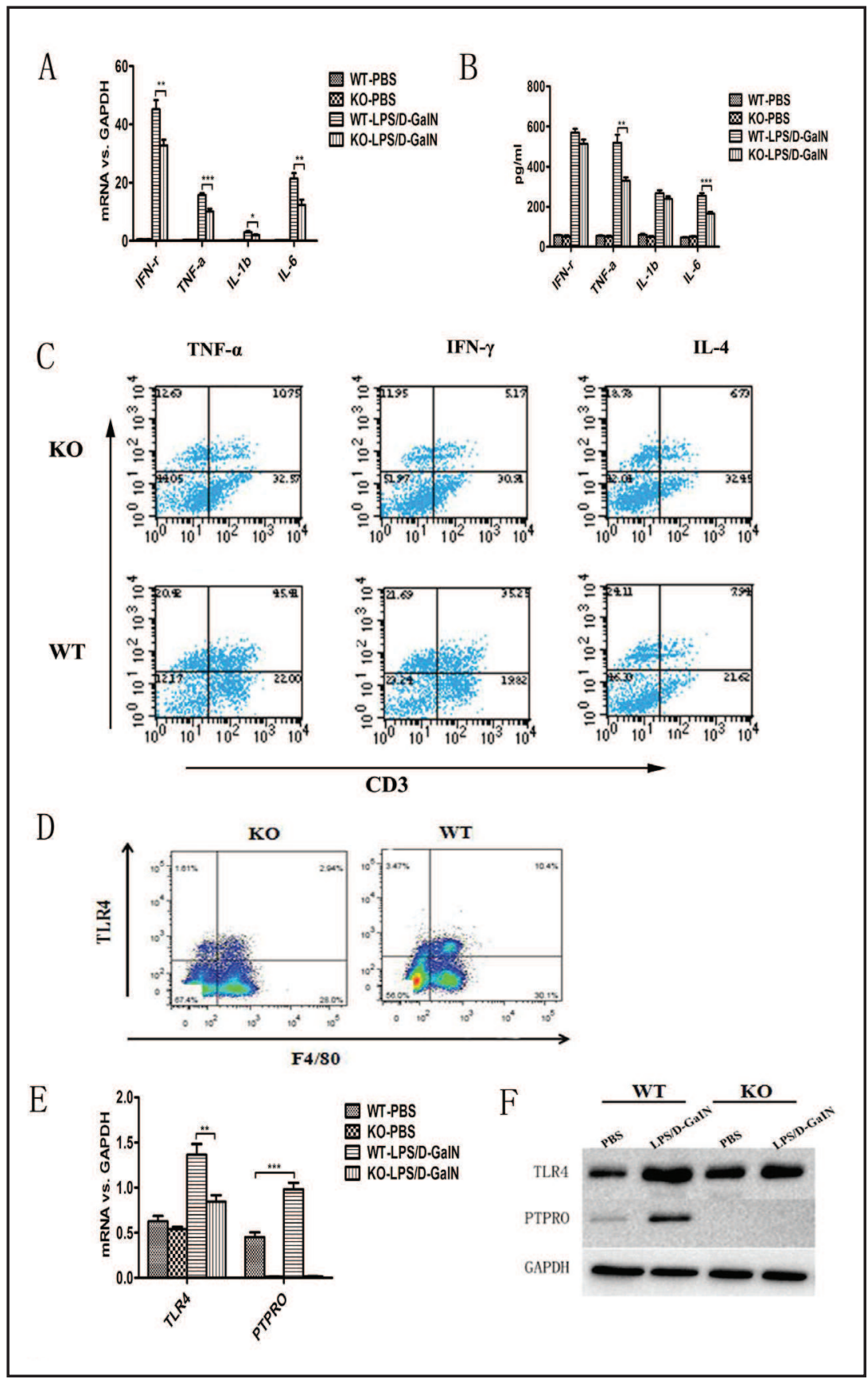

main activated immune cells involved in LPS/D-GaIN induced FH. As shown in Fig. 3D, fewer F4/80+TLR4 ${ }^{+}$cells were detected in the spleen of PTPRO-KO mice. Spleen lymphocytes of PTPRO-WT and -KO mice were also isolated and activated by LPS and D-GaIN in vitro. LPS/DGaIN could increase the expression of TLR4 and PTPRO in spleen lymphocytes of PTPROWT mice; nonetheless, TLR4 could not be up-regulated due to PTPRO depletion (Fig. 3E and 3F). As a result, the attenuated inflammation in PTPRO-KO mice following LPS/D-GaIN injection could be partially attributed to decreased TLR4 expression. TLR4 might contribute to enhanced inflammation and liver damage in LPS/D-GaIN induced FH by interacting with PTPRO. Depletion of PTPRO could in some degree down-regulated TLR4. As a result, we hypothesized that a crosstalk between PTPRO and TLR4 might be involved in acute liver injury, in which NF-kB signaling might act as a fine tune and control the feedback loop. 


\section{Cellular Physiology Cell Physiol Biochem 2015;37:214-224 \begin{tabular}{l|l|l}
\hline DOI: 10.1159/000430346 & (c) 2015 S. Karger AG, Basel
\end{tabular} \begin{tabular}{l|l} 
and Biochemistry Published online: August 20, 2015 & www.karger.com/cpb \\
\hline
\end{tabular}}

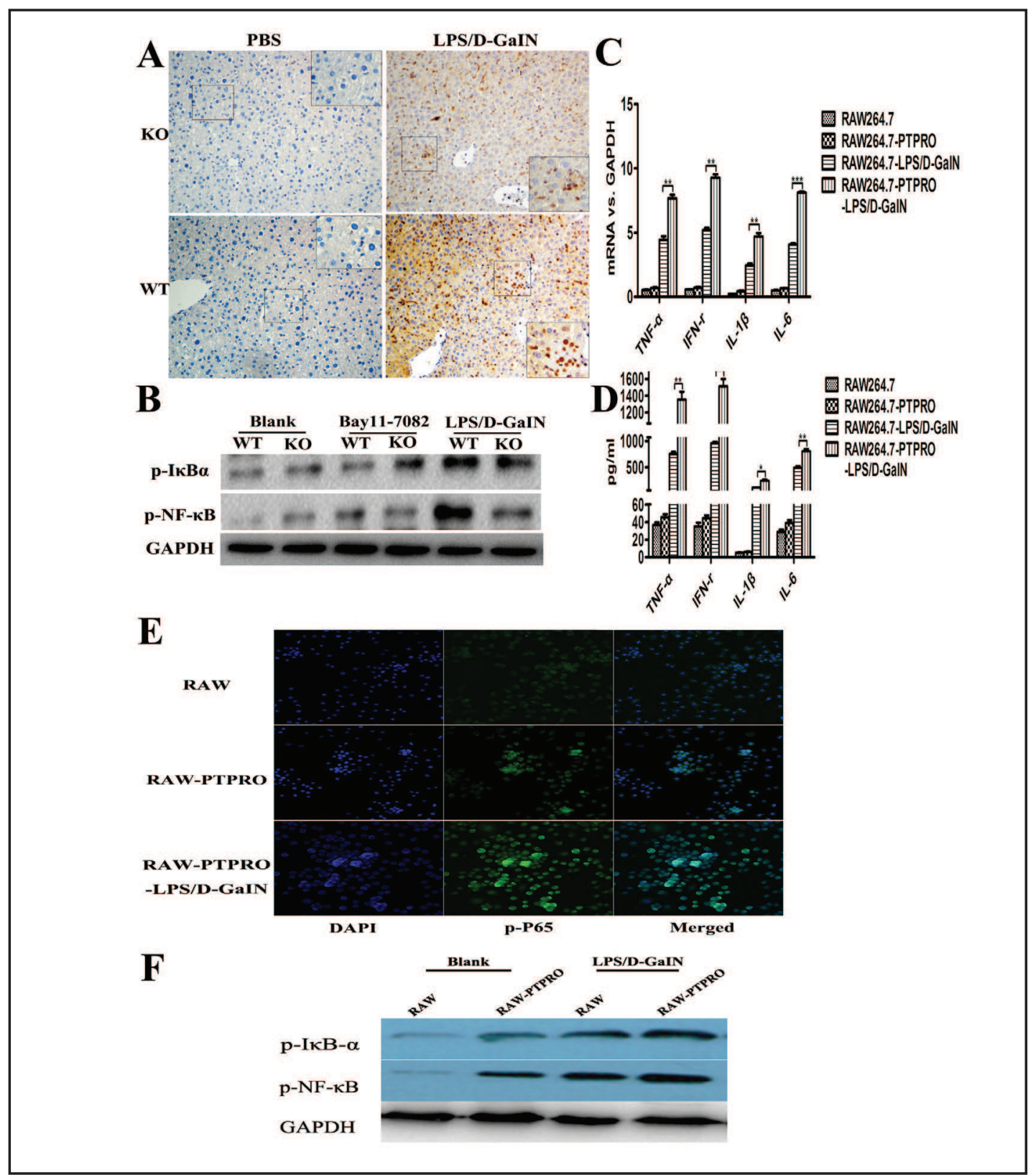

Fig. 4. Effect of PTPRO on the inflammatory response and activation of NF- $\kappa B$ in RAW264.7 cell line. (A) Activation of NF- $\kappa$ B/P65 signaling in mice liver $(n=6)$. (B) Activation of I $\kappa B-\alpha$ and NF- $\kappa B / P 65$ in mice spleen lymphocytes (200X, n=6). (C) Level of IFN-r, TNF- $\alpha$, IL-1 $\beta$ and IL-6 mRNA in RAW264.7 cells (n=3). (D) Level of IFN-r, TNF- $\alpha$, IL-1 $\beta$ and IL-6 protein in RAW264.7 cell medium (n=3). (E) Immunofluorescence for activation and nuclear translocation NF- $\kappa \mathrm{B} / \mathrm{P} 65$ in RAW264.7 cells (X100, n=3). (F) Activation of IкB- $\alpha$ and NF-kB/P65 in RAW264.7 cells (X100, n=3) ( ${ }^{*} P<0.05$, $\left.{ }^{* *} P<0.01,{ }^{* *} P<0.001\right)$.

Positive feedback regulation between PTPRO and TLR4 dependent on NF- $\kappa B$ signaling

With the hypothesis of NF- $\mathrm{\kappa B}$ signaling playing a significant role in the crosstalk between PTPRO and TLR4, we detected its activation and nuclear translocation in mice liver. As shown by H\&E staining, less NF- $\kappa \mathrm{B} / \mathrm{P} 65$ phosphorylation and nuclear translocation in PTPRO-KO

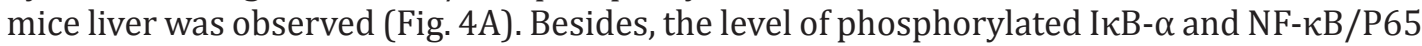
in spleen lymphocytes stimulated by LPS/D-GaIN in vitro was significantly decreased due to PTPRO depletion (Fig. 4B). The up-regulation of NF- $\kappa B$ signaling by LPS/D-GaIN in spleen 


\section{Cellular Physiology $\frac{\text { Cell Physiol Biochem 2015;37:214-224 }}{\text { DOI: 10.1159/000430346 }}$ \begin{tabular}{ll|l} 
and Biochemistry & $\begin{array}{l}\text { DOI: 10.1159/000430346 } \\
\text { Published online: August 20, 2015 }\end{array}$ & $\begin{array}{l}\text { O 2015 S. Karger AG, Basel } \\
\text { www.karger.com/cpb }\end{array}$ \\
\cline { 2 - 3 }
\end{tabular}
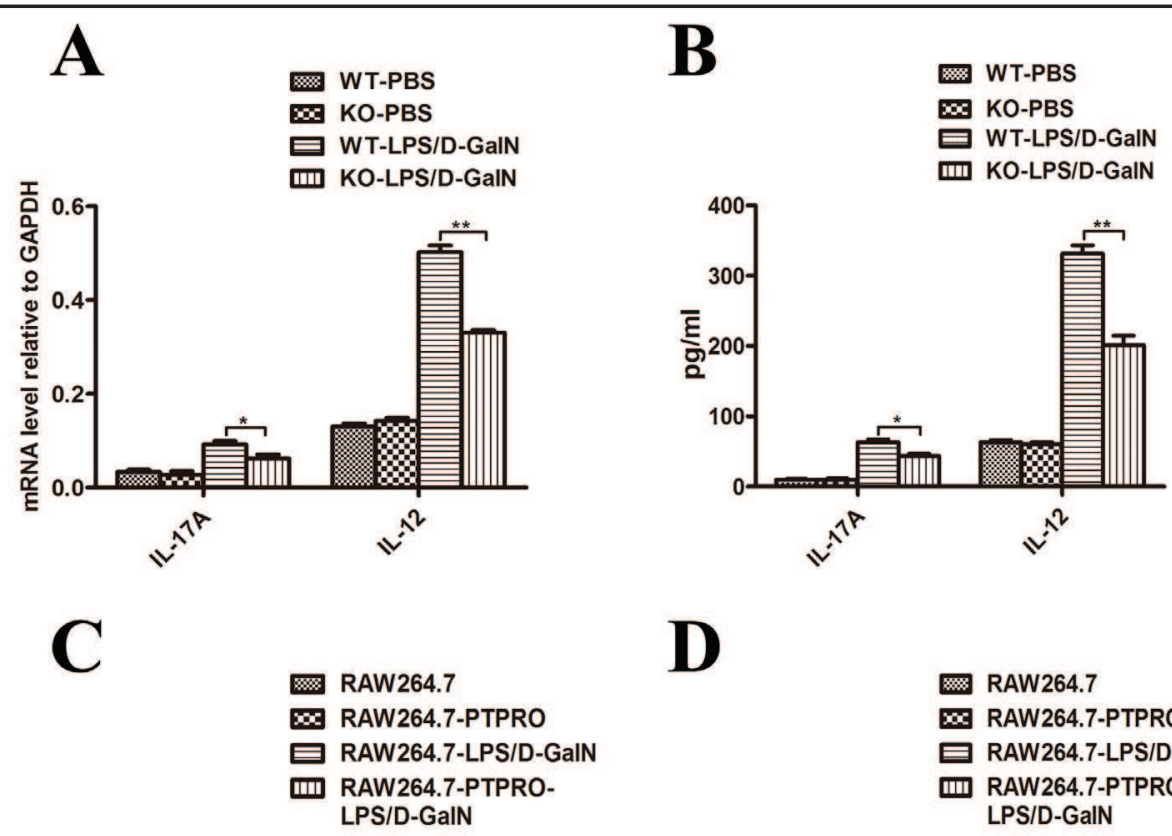

D
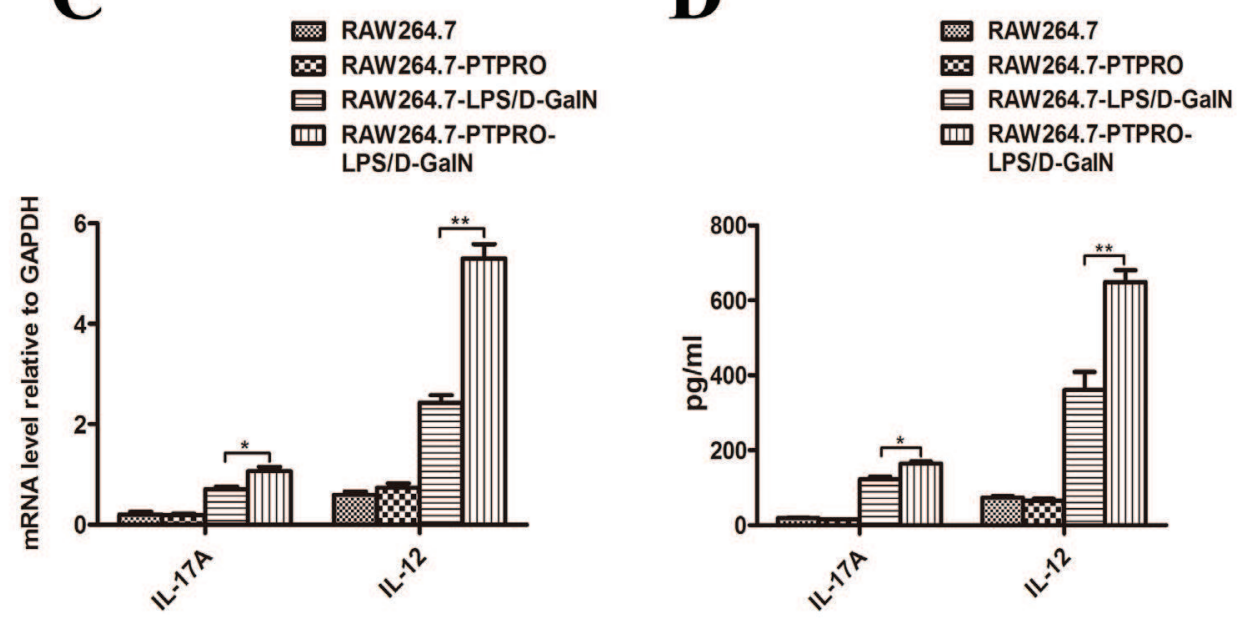

Fig. 5. Level of IL-17A and IL-12 altered in PTPRO knockout mice and PTPRO overexpressed RAW264.7 cell line. (A) Level of IL-17A and IL-12 mRNA in mice liver $(n=6)$. (B) Level of IL-17A and IL-12 protein in mice serum (n=6). (C) Level of IL-17A and IL-12 mRNA in RAW264.7 cells (n=3). (D) Level of IL-17A and IL-12 protein in RAW264.7 cell medium $(\mathrm{n}=3)\left({ }^{*} P<0.05\right.$, $\left.{ }^{* *} P<0.01\right)$.

lymphocytes was remarkably inhibited by specific NF-кB inhibitor, namely, Bay11-7082 (Fig. 4B). Moreover, the feedback regulation between PTPRO and TLR4 was further determined by mouse RAW264.7 macrophages in vitro. PTPRO was over-expressed in RAW264.7 cells (RAW-PTPRO) by transfection as previously described [12]. Cytokines of TNF- $\alpha$, IFN- $\gamma$, IL-1 $\beta$, IL-6, IL-17A and IL-12 were significantly up-regulated in LPS/D-GaIN stimulated RAW-PTPRO cells (Fig. 4C and 4D, Fig. 5C and 5D). In addition, more NF- $\kappa B$ activation and nuclear translocation was found when stimulating RAW-PTPRO cells by LPS and D-GaIN (Fig. $4 \mathrm{E}$ and $4 \mathrm{~F})$.

\section{Discussion}

Previous studies have suggested PTPRO as a tumor suppressor in a number of malignancies including HCC [13-15, 20]. We have found PTPRO is low-expressed in HCC and can inhibit HCC progression by interacting with TLR4/NF- $\kappa B$ signaling $[12,18]$. We have also identified its regulatory effect on T cells-mediated acute liver injury in a ConA induced FH mouse model [17]. However, the role of PTPRO in macrophages-mediated acute liver injury and its potential interaction with TLR4 remains largely unknown. 


\section{Cellular Physiology Cell Physiol Biochem 2015;37:214-224 \\ \begin{tabular}{l|l} 
and Bioch 10.1159/000430346 & $\begin{array}{l}\text { C 2015 S. Karger AG, Basel } \\
\text { www.karger.com/cpb }\end{array}$ \\
\hline
\end{tabular}}

PTPRO, a transmembrane phosphatase, consists of full length and truncated isoforms. The full length isoform, termed PTPRO, is mainly expressed in epithelial cells and the truncated isoform termed PTPROt is particularly expressed in macrophages and lymphocytes [21]. It is one of the most intensively studied members in PTPs family and confers modifying effects on inflammation and inflammation-related cancer. Diethylnitrosamine (DEN) is usually used to construct animal HCC models by inducing sustained and chronic inflammation in liver. In a DEN-induced mouse HCC model, tumor number and size were increased due to PTPRO depletion, which suggested that PTPRO played a vital role in HCC progression by controlling chronic inflammation [18]. Various targets of PTPRO involved in essential tumor-associated cell signaling pathways have been explored, most of which play critical roles in inflammation, such as JAKs and STATs [22, 23]. A number of studies have implicated potential effect of TLR4 on HCC risk and prognosis, but providing inconsistent and inconclusive findings $[10,24]$. TLR4 is not only a foe but a friend for HCC. To the best of knowledge, targeting of inflammation in cancer is not straight-forward and sometimes inflammation may contribute to tumor regression. LPS/TLR4 mediated inflammation is a key component of host defense in killing pathogens, clearance of tissue damage and regeneration [25-27]. We previously elucidated a positive association between PTPRO and TLR4 in HCC [12]. In this study, we for the first time identified an interesting feedback loop However, the interaction between PTPRO and TLR4 in LPS/D-GaIN induced acute necrotic hepatitis, namely, FH.

$\mathrm{FH}$ is a lethal acute liver damage accompanied with complicated disorders of the immune system. Numerous immune cells and inflammatory mediators are involved in HF development and progression, such as T cells, NKT cells, and macrophages as well as their secretory cytokines including TNF- $\alpha$, IFN- $\gamma$, IL-1 $\beta$, and so forth [28, 29]. Accumulative evidence supports that innate immune response to microbes plays an important role in the development of FH through TLRs [4, 5, 30, 31]. Increased expression of TLR4 has been found in status of $\mathrm{HCV}, \mathrm{HBV}$ infection and liver injury $[9,10,32]$. Down-regulated expression and function of TLR4 are pivotally involved in LPS/D-GaIN induced fulminant hepatic damage [8]. LPS/D-GaIN induced acute liver injury is primarily induced by macrophagesmediated immune response through TLR4 and its downstream signaling pathway [8]. It is still unknown whether and how PTPRO in macrophages contributes to the pathogenesis of LPS/D-GaIN induced HF. We, for the first time, demonstrated that depleted expression of PTPRO is responsible for impaired cell function in macrophages and reduced secretion of inflammatory cytokines including TNF- $\alpha$, IFN- $\gamma$, IL-1 $\beta$, IL-6, IL-17A and IL-12. Similar to the modifying effect of PTPRO on ConA-induced FH [17], aggravated liver injury but attenuated inflammation was observed in PTPRO-deficient mice following LPS/D-GaIN administration, which suggested that PTPRO played a dual role in LPS/D-GaIN induced FH by influencing the activation of TLR4/NF- $\kappa B$ signaling. PTPRO in hepatocytes of FH patients was low-expressed in company with decreased NF- $\kappa B$ activation, while PTPRO in immune cells (mainly T cells and macrophages) was high-expressed following increased NF- $\kappa B$ activation [17]. Nevertheless, we failed to determine where PTPRO was highly expressed and whether it was positively associated with the activation of NF- $\kappa B$ in LPS/D-GaIN induced FH mice. We are trying to elucidate this issue in future studies. Our previous study reported that PTPRO also played dual regulatory effects on acute liver injure caused by ischemia reperfusion (IR) [16]. PTPRO conferred contrary effects at different time points of IR, early as an inflammation promoter and successively as an inflammation inhibitor [16]. Taken together, PTPRO is a good target for regulating acute inflammation-related liver diseases.

$\mathrm{NF}-\kappa \mathrm{B}$ is a crucial transcript factor participating in inflammation, innate immune and adaptive immune [33]. Activated NF- $\kappa B$ exacerbates inflammatory response and intensifies liver injury by regulation of plentiful pro-inflammatory and anti-inflammatory cytokines $[34,35]$. PTPRO has been shown to influence the activation of transcription factors NF$\kappa \mathrm{B}$ and STAT3, which mediate classical inflammation-related signaling pathways involved in hepatitis and HCC $[17,18]$. We demonstrated a novel PTPRO/TLR4/NF- $\kappa B$ signaling feedback loop in FH and HCC. Decreased spleen infiltrative lymphocytes and markedly weakened NF- $\kappa B$ signaling activation accounted for attenuated inflammation in FH. 


\section{Cellular Physiology Cell Physiol Biochem 2015;37:214-224 \begin{tabular}{c|c}
\hline DOI: 10.1159/000430346 & (c) 2015 S. Karger AG, Basel
\end{tabular} $\begin{array}{ll}\text { and Biochemistry Published online: August 20, } 2015 & \begin{array}{l}\text { C) 2015 S. Karger AG, } \\ \text { www.karger.com/cpb }\end{array}\end{array}$ \\ Wang et al.: PTPRO and TLR4 in Fulminant Hepatitis}

Additionally, high level of activation and nuclear translocation of NF- $\mathrm{KB}$ were observed in PTPRO over-expressed RAW264.7, which further elucidated the positive feedback between PTPRO and TLR4 was via NF- $\kappa$ B signaling. Nonetheless, no strong and immediate evidence was shown to elucidate how PTPRO interacted with TLR4. Further research is warranted for investigation. Furthermore, more studies are encouraged to investigate the potential role of other molecules, such as STAT3, and the interplay between STAT3 and NF- $\mathrm{kB}$ pathways in FH, as well as their crosstalk previously elucidated in HCC [18].

In conclusion, we firstly show strong evidence for a crosstalk between PTPRO and TLR4 depending on the activation of NF- $\mathrm{KB}$ signaling in LPS/D-GaIN induced FH. Our data in combination with previous findings further suggest that PTPRO and TLR4 may be promising therapeutic targets for hepatitis and HCC.

\section{Acknowledgments}

This work was supported by grants from the National Natural Science Foundation for Distinguished Young Scholars (81225017 to B.S.), National Basic Research Program of China (2012CB910800 to B.S.), and National Natural Science Foundation (81430062 to B.S.; 81302106 to J.H.; 81201528 to R.J.). This work also supported in part by the program for Development of Innovative Research Team in the First Affiliated Hospital of NJMU, and the Priority Academic Program of Jiangsu Higher Education Institutions. B.S. is Yangtze River scholars Distinguished Professor.

\section{Disclosure Statement}

Authors involved have contributed adequately to this work and have no conflicts of interest to disclose.

\section{References}

1 Agrawal BK, Agrawal U: Acute liver failure. N Engl J Med 2014;370:1170.

2 Lee WM: Acute liver failure. Semin Respir Crit Care Med 2012;33:36-45.

3 Bernal W, Wendon J: Acute liver failure. N Engl J Med 2014;370:1170-1171.

4 Chen Y, Sun R: Toll-like receptors in acute liver injury and regeneration. Int Immunopharmacol 2011;11:1433-1441.

5 Wang X, Sun R, Wei H, Tian Z: High-mobility group box 1 (hmgb1)-toll-like receptor (tlr)4-interleukin (il)23-il-17a axis in drug-induced damage-associated lethal hepatitis: Interaction of gammadelta t cells with macrophages. Hepatology 2013;57:373-384.

6 Yang Q, Shi Y, He J, Chen Z: The evolving story of macrophages in acute liver failure. Immunol Lett 2012;147:1-9.

7 Xie C, Jingjing W, Li X, Zeng F, Ma L, Li C, Wei Z, Peng A, Chen L: Protective effect of sklb010 against d-galactosamine/lipopolysaccharide-induced acute liver failure via nuclear factor-kappab signaling pathway in macrophages. Int Immunopharmacol 2014;21:261-268.

8 Ben Ari Z, Avlas O, Pappo O, Zilbermints V, Cheporko Y, Bachmetov L, Zemel R, Shainberg A, Sharon E, Grief F, Hochhauser E: Reduced hepatic injury in toll-like receptor 4-deficient mice following d-galactosamine/ lipopolysaccharide-induced fulminant hepatic failure. Cell Physiol Biochem 2012;29:41-50.

9 Zare-Bidaki M, Tsukiyama-Kohara K, Arababadi MK: Toll-like receptor 4 and hepatitis b infection: Molecular mechanisms and pathogenesis. Viral Immunol 2014;27:321-326.

10 Wang Z, Yan J, Lin H, Hua F, Wang X, Liu H, Lv X, Yu J, Mi S, Wang J, Hu ZW: Toll-like receptor 4 activity protects against hepatocellular tumorigenesis and progression by regulating expression of DNA repair protein ku70 in mice. Hepatology 2013;57:1869-1881.

11 Yu LX, Yan HX, Liu Q, Yang W, Wu HP, Dong W, Tang L, Lin Y, He YQ Zou SS, Wang C, Zhang HL, Cao GW, Wu MC, Wang HY: Endotoxin accumulation prevents carcinogen-induced apoptosis and promotes liver tumorigenesis in rodents. Hepatology 2010;52:1322-1333.

12 Xu D, Wang X, Yan S, Yin Y, Hou J, Wang X, Sun B: Interaction of ptpro and tlr4 signaling in hepatocellular carcinoma. Tumour Biol 2014;35:10267-10273. 


\section{Cellular Physiology Cell Physiol Biochem 2015;37:214-224 \begin{tabular}{l|l}
\hline DOI: 10.1159/000430346 & (c) 2015 S. Karger AG, Basel
\end{tabular} and Biochemistry Published online: August 20, $2015 \quad$ www.karger.com/cpb \\ Wang et al.: PTPRO and TLR4 in Fulminant Hepatitis}

13 Huang YT, Li FF, Ke C, Li Z, Li ZT, Zou XF, Zheng XX, Chen YP, Zhang H: Ptpro promoter methylation is predictive of poorer outcome for her2-positive breast cancer: Indication for personalized therapy. J Transl Med 2013;11:245.

14 Li SY, Li R, Chen YL, Xiong LK, Wang HL, Rong L, Luo RC: Aberrant ptpro methylation in tumor tissues as a potential biomarker that predicts clinical outcomes in breast cancer patients. BMC Genet 2014;15:67.

15 Motiwala T, Kutay H, Ghoshal K, Bai S, Seimiya H, Tsuruo T, Suster S, Morrison C, Jacob ST: Protein tyrosine phosphatase receptor-type o (ptpro) exhibits characteristics of a candidate tumor suppressor in human lung cancer. Proc Natl Acad Sci U S A 2004;101:13844-13849.

16 Hou J, Xia Y, Jiang R, Chen D, Xu J, Deng L, Huang X, Wang X, Sun B: Ptpro plays a dual role in hepatic ischemia reperfusion injury through feedback activation of nf-kappab. J Hepatol 2014;60:306-312.

17 Jiang R, Chen D, Hou J, Tan Z, Wang Y, Huang X, Wang X, Sun B: Survival and inflammation promotion effect of ptpro in fulminant hepatitis is associated with nf-kappab activation. J Immunol 2014;193:5161-5170.

18 Hou J, Xu J, Jiang R, Wang Y, Chen C, Deng L, Huang X, Wang X, Sun B: Estrogen-sensitive ptpro expression represses hepatocellular carcinoma progression by control of stat3. Hepatology 2013;57:678-688.

19 Aminin DL, Silchenko AS, Avilov SA, Stepanov VG, Kalinin VI: Cytotoxic action of triterpene glycosides from sea cucumbers from the genus cucumaria on mouse spleen lymphocytes. Inhibition of nonspecific esterase. Nat Prod Commun 2009;4:773-776.

20 Motiwala T, Ghoshal K, Das A, Majumder S, Weichenhan D, Wu YZ, Holman K, James SJ, Jacob ST, Plass C: Suppression of the protein tyrosine phosphatase receptor type o gene (ptpro) by methylation in hepatocellular carcinomas. Oncogene 2003;22:6319-6331.

21 Matozaki T, Murata Y, Mori M, Kotani T, Okazawa H, Ohnishi H: Expression, localization, and biological function of the $\mathrm{r} 3$ subtype of receptor-type protein tyrosine phosphatases in mammals. Cell Signal 2010;22:1811-1817.

22 Newton K, Dixit VM: Signaling in innate immunity and inflammation. Cold Spring Harb Perspect Biol 2012;4

23 O'Shea JJ, Plenge R: Jak and stat signaling molecules in immunoregulation and immune-mediated disease. Immunity 2012;36:542-550.

24 Naugler WE, Sakurai T, Kim S, Maeda S, Kim K, Elsharkawy AM, Karin M: Gender disparity in liver cancer due to sex differences in myd88-dependent il-6 production. Science 2007;317:121-124.

25 Grivennikov SI, Greten FR, Karin M: Immunity, inflammation, and cancer. Cell 2010;140:883-899.

26 Ren JL, Pan JS, Lu YP, Sun P, Han J: Inflammatory signaling and cellular senescence. Cell Signal 2009;21:378383.

27 Jia HY, Chen F, Chen JZ, Wu SS, Wang J, Cao QY, Chen Z, Zhu HH: Microrna expression profiles related to early stage murine concanavalin a-induced hepatitis. Cell Physiol Biochem 2014;33:1933-1944.

28 Kang SG, Liu WH, Lu P, Jin HY, Lim HW, Shepherd J, Fremgen D, Verdin E, Oldstone MB, Qi H, Teijaro JR, Xiao C: Micrornas of the mir-17 approximately 92 family are critical regulators of $t(f h)$ differentiation. Nat Immunol 2013;14:849-857.

29 Karnowski A, Chevrier S, Belz GT, Mount A, Emslie D, D'Costa K, Tarlinton DM, Kallies A, Corcoran LM: B and $t$ cells collaborate in antiviral responses via il-6, il-21, and transcriptional activator and coactivator, oct2 and obf-1. J Exp Med 2012;209:2049-2064.

30 Hoque R, Farooq A, Ghani A, Gorelick F, Mehal WZ: Lactate reduces liver and pancreatic injury in toll-like receptor- and inflammasome-mediated inflammation via gpr81-mediated suppression of innate immunity. Gastroenterology 2014;146:1763-1774.

31 Zhang Q, Raoof M, Chen Y, Sumi Y, Sursal T, Junger W, Brohi K, Itagaki K, Hauser CJ: Circulating mitochondrial damps cause inflammatory responses to injury. Nature 2010;464:104-107.

32 Vespasiani-Gentilucci U, Carotti S, Onetti-Muda A, Perrone G, Ginanni-Corradini S, Latasa MU, Avila MA, Carpino G, Picardi A, Morini S: Toll-like receptor-4 expression by hepatic progenitor cells and biliary epithelial cells in hcv-related chronic liver disease. Mod Pathol 2012;25:576-589.

33 Yan J, Xiang J, Lin Y, Ma J, Zhang J, Zhang H, Sun J, Danial NN, Liu J, Lin A: Inactivation of bad by ikk inhibits tnfalpha-induced apoptosis independently of nf-kappab activation. Cell 2013;152:304-315.

34 Kuboki S, Sakai N, Clarke C, Schuster R, Blanchard J, Edwards MJ, Lentsch AB: The peptidyl-prolyl isomerase, pin1, facilitates nf-kappab binding in hepatocytes and protects against hepatic ischemia/ reperfusion injury. J Hepatol 2009;51:296-306.

35 Sakon S, Xue X, Takekawa M, Sasazuki T, Okazaki T, Kojima Y, Piao JH, Yagita H, Okumura K, Doi T, Nakano H: Nf-kappab inhibits tnf-induced accumulation of ros that mediate prolonged mapk activation and necrotic cell death. ЕМBO J 2003;22:3898-3909. 